\title{
顎＼cjkstart骨（III） 167〜172
}

\section{座長のまとめ}

瀬戸 晥一（鶴見大学 $($ 歯) 第 1 口腔外科)

演題167，168，169 はいずれも下頡骨の再建に関する 報告である。下顎の再建は, 咀嚼筋力による偏位の問 題, 形態賦与の困難, 義歯の澦堤としての機能の必要性 など, 多くの臨床的な問題を有し，一般に非常に難しい とされている。特に口底, 舌腫演において下顎骨と周囲 軟組織を大きく一塊摘出する場合には, 顎口腔諸機能お よび審美性の回復を 達成することは決して容易ではな く, 本学会でもしばしば大きな論議を呼んでいるテーマ である。

演題167の森田らは, Titanium mesh tray を用いて 下頡骨を再建し, 少数例ながら良好な成績を挙げてい る。最近とくに骨移植によらず，セラミックスなどの生 体材料を用いて再建することがよく行われているが，本 題においては金属材料とくに Titanium の有用性が見直 される結果が報告された。今後骨移植, 他の骨代用材と の併用, 皮弁との兼祦合いなど綿密な手術術式の開発が 望まれる。

演題168 の窪田らは, アルミナおよびアパタイトを用 いた下顎骨再建例が報告された。下顎骨再建 8 例中 3 例 にアパタイトを，5例にアルミナを適用し，成績は成功 例 4 例で，良好例はいずれも MC 皮弁で被覆したもの であったことは注目された。質問は成績不良例の原因に ついて集中した。アルミナは bioinert material であり, また手術場での加工が不可能なことがアパタイトに比べ て不利である。またセラミックス材料を用いる再建では 小さな死腔も失敗の原因となり, 特に粘膜の被覆, 縫合 が重要であろうと思われた。

演題169の白川らの報告は, 下顎切除患者の術後の顎 運動機能を経時的に調べたものである。これによると下
頡の欠損範囲が大きくても顎関節頭が 保存されていれ ば，顎運動障害はわずかで， 2 年後には改善された。し かし人工顎関節頭の場合は術直後の偏位は較度であった が，長期間 follow すると偏位の程度は增長するとして いる。再建の効果は術後長期間を経てはじめて評価され るべきものであろう。

演題170, 山城らの報告は, 口底癌にて再発時を含め 2 回にわたる放射線治療により，両側顎角部から下顎骨 体全域が腐骨となり分離した珍しい症例に関するもので あった。元来口底あるいは下顎癌は再建手術が発達して いる現在，手術を第一選択とするべきものと考えられる が，本例は全身的に手術不適応であったため止むを得な かったものと思わ秃る。下顎骨や口底の放射線治療の難 しさがあらためて認識させられた 1 例であった。

演題 171 , 小林らは肺澏より歯肉に転移した 2 例を報 告した。歯肉部には腫瘤性病変がよく出現し, その中で 転移性腫瘍はごく稀なので，診断にあたって忘れがちで あるが，今回の 2 例は初診時より転移性癌を疑って生検 がなされ，内科との連携がうまく行われた症例であった と思われる。

演題172，飯田らは下顎骨骨肉腫の 1 例を報告した。 近年の放射線治療, 化学療法の進歩にも拘らず, 依然と して骨肉腫の治療の主体は手術であり，本例でも術前に 化学療法を多剤併用してまず腫瘍の activity を減弱せ しめ，その後に一塊摘出手術を行い，良好な結果を得て いる。下頻の即時再建などを敢えて行わず，歯科的手段 で口腔機能の保存と回復に努められたことは本疾患にお いては最も適切な選択と考えられるが，なお長期間の厳 重な経過観察が必要であらう。 


\section{Titanium mesh tray による下顎骨の再建例}

森田章介・飯田武・小川 文也 (大阪歯科大学・ 口腔外科第 2 講座)

下顎切除後の下顎骨再建にはいまだ確立された理想的 な方法がなく,術式の選択に苦慮するものである。われわ れは titanium mesh tray による下顎骨の再建を試み, 良い結果を得ているので報告する。今回使用した mesh tray は米国 $3 \mathrm{M}$ 社製のものであった。

症例の概要は表に示すように，年齢は22歳から60歳ま でで, 男性 2 例, 女性 3 例であった。診断は歯肉口腔底 癌 2 例, 下顎歯肉癌, 下顎骨中心性癌およびエナメル上 皮腫が各々 1 例であった。覀性腫湯切除後の再建にはす べて皮弁を用い，その内分けは D.P 皮弁 1 例, 頸部島 状皮弃 3 例であった。また症例 2 を除き, 腸骨移植を併 用した。下顎骨の切除範囲は片側骨体部 2 例, 両側骨体 部に及ぶもの1例，骨体部から下顎枝および関節突起頸 部に及ぶもの各々 1 例であった。残存骨と mesh tray と の固定は titanium screw や titanium wire にて行なっ た。術後の観察期間は 8 力月から 3 年で, 平均 1 年 6 力 月であったが, mesh tray の露出や除去を余儀なくされ た症例はなかった。症例 2 は術後 9 力月で脳転移にて死 亡したが，局所再発は認められなかった。他の症例む現 在局所再発は認められず, 義歯を装着しており, 顔貌も 満足できるものである。なお症例 1 ○ の悪性腫湯例に 対しては, 全例 ${ }^{60} \mathrm{Co}$ 外照射を $22 \mathrm{~Gy}$ から $40 \mathrm{~Gy}$ 術前に行 なった。

下顥骨の再建用材料として現在各種のものが用いられ ている。titanium は金属材料のなかで最も生体親和性が 良いと云われているが，mesh tray を用いた下顎骨の再 建についての報告はほとんどみられない。今回われわれ が本製品を用いた理由として，

（1）既製品を術中容易に 比較的任意の 形状に 修正で き，残存骨と適合させ易いなど操作性が良好である。

(2) titanium screw や titanium wire で残存骨に容 易に固定できる。

（3）周囲組織との親和性にすぐれ，永久義䪽になり得 る。

（4）block 骨や骨髄を含む海綿骨梁移植の併用が容易 である。

（5）他の再建用金属に比べ非常に軽量で，しかも薄く メッシュ状であるため, 孔を通じて結合組織が密に連結 し，周囲組織と義顎との結合が強固である。

などがあげられ，即時再建にはすぐれていると考えてい る。しかし，本製品の形状は全下顎用，片側骨体部用， オトガイ〜骨体部用および下顎角部用しかなく，しかも これらは欧米人の骨格に適しており，大きさむ 1 種類の ため，邦人ことに女性には不適合な場合がある。最近医 療用 titanium の加工が容易になったため，われわれは 種々のサイズのものを製作し使用している。しかし，術 後の放射線治療の妨げとなることも考えられる。さらに sulcus や歯槽堤の形成が容易でないため，骨移植の併用 や，口腔内の被覆に用いる皮弁の大きさおよび縫合操作 などに検討を加える必要がある。

Titanium mesh tray による下䫟骨の再建症例

\begin{tabular}{|c|c|c|c|c|c|c|c|}
\hline 症 例 & 年齡 & 性 & 断 & 手 術 法 & 下䭭骨の切除範囲 & 钽察期間 & 備 \\
\hline 1.E.K.. & 37 & $\hat{\delta}$ & 歯肉口腔底癌 & 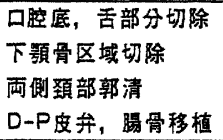 & & 2年9力月 & 術前照射 22 Gy \\
\hline 2. J.M. & 36 & 우 & 下頻骨中心性癌 & $\begin{array}{l}\text { 下䫑骨区域切除 } \\
\text { 応側頚部郭清 } \\
\text { 預部岛状皮弁 }\end{array}$ & & 9 カ月 & $\begin{array}{l}\text { 術前照射 } 40 G y \\
\text { 㭪後9月で媨転移にて } \\
\text { 死亡。局所登はなかった。 }\end{array}$ \\
\hline 3.Y.M. & 53 & 오 & 下頻歯肉癌 & 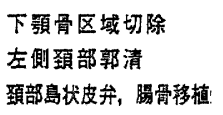 & & 8カ月 & 術前照射 $30 \mathrm{~Gy}$ \\
\hline 4.H.Y. & 60 & $\hat{\delta}$ & 歯肉口膑底癌 & 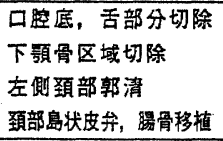 & & 8 カ月 & 術前照射 $30 \mathrm{~Gy}$ \\
\hline 5.C.K. & 22 & 우 & エナメル上皮腪 & $\begin{array}{l}\text { 下預骨区域切除 } \\
\text { 晹骨移植 }\end{array}$ & & 3年 & $\begin{array}{l}\text { 14藏時に下頻骨区域场除 } \\
\text { 路骨移植 }\end{array}$ \\
\hline
\end{tabular}




\section{8. 七ラミックスによる頭頸部癌摘出後の骨再建}

\section{涳田 哲昭・吉田 篤正・海野 博之・堀 雅明 田中 裕之・宮尾源二郎}

（昭和大学藤が丘病院・耳鼻咽喉科）

セラミックスは骨組織に代る新しいバイオステリアル として近年注目されているものであり，整形外科領域で は既に多方面にわたって多くの臨床例に使用されてい る。頭頸部腫瘍外科においても再建材料として興味をも たれつつあるが，我々の報告を含め $2 \sim 3$ の施設での数 少い試用があるのみであり，その成績も必ずしも良好と はいえない。

我々は最近 4 年間においてセラミックスによる骨再建 即ち下頭骨及び眼窩底骨の再建を行い, 術後 1 年以上に わたって経過を観察し得た症例について報告する。

I . 下䫁骨再建について

症例は舌及び口腔癌にて下䇗骨切除を行った10例であ る（表1）。セラミックスはアパタイトを使用したもの が 3 例，うち 2 例が下顎骨辺縁切除例， 1 例が区域切除 例である。多結晶アルミナは 5 例に適応し全例とも下頭 骨を完全離断した区域切除例である。セラミックスの形 状は区域切除の場合術前に切除範囲を計画し，下䫟骨の 正側 2 方向及び軸位のレ線写真と下顎骨弓の実測值より 前もって作製準備しておいた。骨との固定はアパタイト ではワイヤーで，アルミナでは単結晶サファイヤースク リューで行った。

成績は経過良好例 4 例であった。又失敗例は 4 例で, その原因を見ると被覆物の壊死によるセラミックスの露 出( 2 例)，ワイヤー固定部の離脱( 1 例), 唾液瘦より骨 壊死 (1 例) で, 逆に良好例では全て MC-flap にて被 覆した場合であった。従って(1) 唾液瘦が 起りやすく骨 壊死が 起りやすい。(2)被覆皮虞や粘膜がセラミックス のため下層からの血行が得られにくく，壊死を起しやす い。(3) 照射や手術のための血行障害が影響しやすい。な どの点に留意して症例を選び，MC-flap など血行の良い 被覆物を使用すれば良好の結果を得られると思われた。

\section{II. 眼窩底骨の再建}

上滪癌の上方進展型で眼熺底や眼窩内容の一部を除去 した場合に起る眼球の宿没を防ぐため，眼球集結用アル ミナ・セラミックスペーサーを我々が考案し眼窩底骨の 再建を行った。これは単結晶アルミナ・セラミックの螺 子により，上領骨煩骨突起上に固定する。本法は 2 例に 行い, 術後の眼球変位と複視を最小限にとどめ経過良好 である。
表 1 セラミックス使用例

\begin{tabular}{|c|c|c|c|c|c|}
\hline & & 症 & 骨切除範囲 & 被覆物 & セラミックス経過 \\
\hline \multirow{3}{*}{$\begin{array}{l}\text { P } \\
\text { 的 } \\
\text { 1 }\end{array}$} & 1 & 52才、舌 癌 & $3 \mathrm{~cm}$ 辺緑 & $D-P$ & 箈出除去 \\
\hline & 2 & 63才、舌癌 & $3 \mathrm{~cm}$ 辺緑 & $M-C$ & \\
\hline & 3 & 70才、选肉偠 & $4 \mathrm{~cm}$ 区域 & 腱 合 & $\begin{array}{l}\text { ワイヤー固定 } \\
\text { 離脱、除去 }\end{array}$ \\
\hline & 4 & 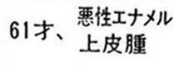 & $4 \mathrm{~cm}$ 区域 & $\begin{array}{l}\text { 下喕部 } \\
M C\end{array}$ & 良 \\
\hline $\boldsymbol{P}$ & 5 & 63才、口腔底漓 & $3 \mathrm{~cm}$ 区域 & $\begin{array}{l}\text { 口腔内 } \\
\text { MC }\end{array}$ & 良 \\
\hline$\Sigma$ & 6 & 56才、舌 & $3 \mathrm{~cm}$ 区域 & $\begin{array}{l}\text { 口腔内 } \\
M C\end{array}$ & 良 \\
\hline ナ & 7 & 69才、口腔底癌 & $4 \mathrm{~cm}$ 区域 & $\begin{array}{l}\text { 口腔内 } \\
\text { MC }\end{array}$ & $\begin{array}{l}\text { 喠液搷、骨壊死、 } \\
\text { 離脱 }\end{array}$ \\
\hline & 8 & 59才、柴肉漓 & $4 \mathrm{~cm}$ 区域 & 縫 合 & 露出除去 \\
\hline
\end{tabular}
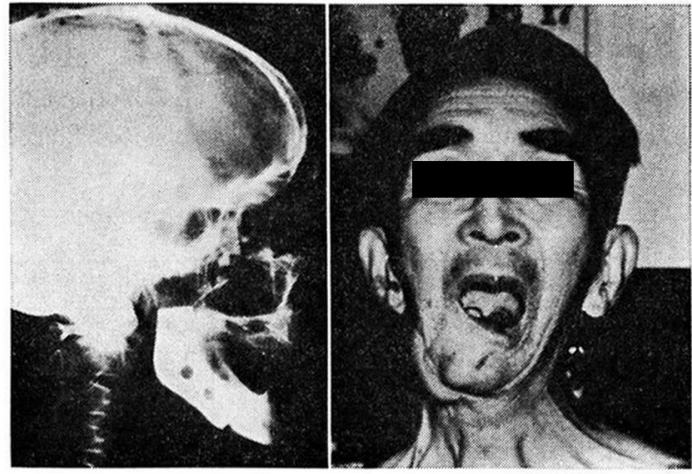

図 1 症例 4 の術後

III. 動物実験について

家鬼の大腿骨にバーにて円形な小穴を開け，本法に主 として用いた多結晶アルミナセラミックの細小ブロック （ $2 \times 2 \times 5 \mathrm{~mm}$ の角柱）を挿入した。 3 力月後にト殺 しアルミナ・セラミックと骨との関係を見るため骨切片 を作製、レ線及び組織学的に検索した。ブロック周囲の 間隙は新生骨により埋められており，両者の親和性は良 好で，互いに接合を密にするものと思われた。従って， セラミックスは頭頸部領域の再建に使用することが可能 で，自家骨採集のための手術侵襲を減らし，形状や大き さに関係なく骨再建ができ有効なものと考えられた。 


\section{9. 下顎顎切除患者の臨床的検討}

一一金属プレート応用例について——

白川 正順 - 長谷川秀行 - 河合 貴久 (町田市民病院・口腔外科)

内田稔・園山昇

(日本歯科大学・口䐋外科学第 2 講座)

広範な下䫟骨切除後の顎欠損等によって生じた顎口腔 系機能の障害ならびに審美障害は患者の日常生活に重大 な支障を招来する。そのため，從来よりこれらの障害を 改善するため新鮮自家腸骨移植あるいは金属プレートの 併用により下䫟再建が広く行われている。しかしなが ら，再建後の䅡口腔系機能の客観的判定に基づく報告は 少なく，かえりみられていないといらのが現状である。 そこで演者らは第 8 回頭頸部腫場学会 (久留米) におい

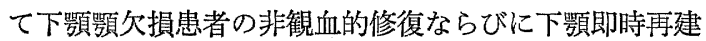
術後の顎運動機能を非接触型下䇗運動解析装置を用いて 定量的に分析した。

今回は再建後の 顎運動機能の 客観的判定を 目的とし て，金属プレートを応用した下頡即時再建例のうち，半 側範囲内の切除症例 9 例を選択し, その切除範囲により 下顎再建術後の䫟運動機能の経時的推移について各症例 群を比較検討した。その結果，若干の知見を得たのでそ の概要を報告した。

\section{検索対象}

A 群 : 下顎枝保存し得た連続離断症例群（4 例)

$\mathrm{B}$ 群 : 関節頭をぎりぎり保存し得た半側切除に近い症 例群 ( 3 例)

C群 : 下顎半側切除し人工間節骨頭を再建した症例群 (2 例)

\section{検索結果}

$\mathrm{A}$ 群 : 6 力月後の開閉口時, 前後的瀕運動時の運動制 限ならびに患側への偏位が著明に認められたが24カ月後 では運動制限，偏位は殆んど改善された。咬合時の偏位 は 6 カ月，24カ月ともに認められなかった。

$\mathrm{B}$ 群 : 6 力月後の開閉口時, 前後的運動で患側への偏 位，側方への運動制限が 認められたが 24 カ月後では偏 位，運動制限の改善傾向が観察された。咬合時の偏位は 6 カ月にも24カ月にも認められなかった。

C 群： 6 カ月後の前後的運動時の偏位, 制限が著しい にも拘らず, 開閉時, 側方運動時の偏位, 制限が軽度で あった。しかしながら24カ月後では前後的，開閉口時，
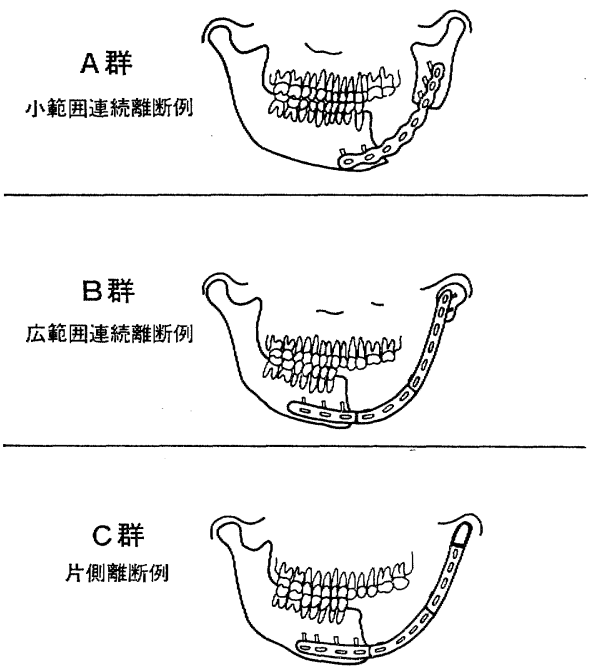

図 検索対象群の分類 一切除範囲と再建図一

患側への著しい偏位を認めた。また，咬合時の偏位が 24 カ月後に出現した。

すなわち，1）関節頭保存例は切除範囲に拘らず顎の 再構築が得られ，さらに経時的に安定した。2）片側離 断例は初期には関節保存例と同様の顎の構築が得られた が，経時的な乱れが観察された。

まとめ

以上の結果をまとめてみると顎の切除範囲によって顎 再建後の顎咬合機能の改善度が異ることが経験的に推察 されたが本研究結果から臨床的な認識と三次元的, 客観 的判定とはほぼ一致し，これを裹付けた。すなわち，関 節頭保存群と人工関節骨頭群に大別して比較検討すると 前者の顎運動にみられる臨床的意義は大であり, 䫟再建 後の顎咬合機能は連続離断の範囲に拘らず両倁関節頭の 連続した結合が重要である結論を得た。 


\title{
170. 両側の下顎骨骨体分離をきたした放射線骨壊死症例
}

\author{
山城 正宏・中野 政雄 \\ (琉球大学・歯科口腔外科, 放射線科) \\ 堀内 淳一・竹田 正宗・天笠 光雄 - 塩田 重利 \\ (東京医科歯科大学・放射線科，第 1 口腔外科) \\ 小守 昭 \\ (徳島大学 (歯) ・ 口腔病理)
}

口腔底癌の放射線治療後に, 両側におよぶ下顎骨骨体 の自然分離をきたした, いわゆる放射線骨壊死症例を経 験したので報告する。

患 者: 68歳, 男性

初 診: 昭和53年12月 5 日

主 訴：口腔底部の腫瘤

既往歴 : 46 47年前フィラリアに罹患, 1 年前まで夕 バコ 20 本 $/ 1$ 日

家族歴 : 父が喉頭癌にて死亡

現病歴 : 4 力月程前, 口腔底部に小指頭大の腫瘤に気 付き，精査のため当科を受診した。

現 症 : 口腔底部に約 $2.5 \times 2 \mathrm{~cm}$ 大の無痛性腫瘤が あり，その周辺に硬結がみられた。腫瘤の前方は舌側歯 槽部と癒着していた。顎下リンパ節は右大豆大, 左小豆 大の可動性腫脹を触れた。胸部X線所見はとくに異常を 認めなかった。同日試験切除を行ない, 病理組織学的に 中等度分化型の扁平上皮癌と診断された。

\section{診 断}

口腔底癌 $\left(\mathrm{T}_{2} \mathrm{~N}_{0} \mathrm{M}_{0}\right)$

\section{処置および経過}

BLM 45mg 使用後, 同年12月13日東京医科歯科大学 病院を受診して放射線治療を行なった。テレコバルト40 Gy（BLM 同時併用 $80 \mathrm{mg}$ ）に続いて，放射線金粒子刺 入 (約60Gy) を施行して腫瘍の消失をみた。以後当科に て FT207+PSK の内服を続けた。

照射終了 2 年後の昭和56年 3 月 24 日, 口腔底より舌側 歯肉に潰瘍を形成したので, 試験切除を行ない再発と診 断された。手術目的で検查を行なったところ自己の赤血 球抗体 (+) で, 輸血不適合のため手術を中止して, 再 度放射線治療を行なった。テレコバルト $20 \mathrm{~Gy}$ と放射線 金粒子による mould 装着（60Gy/120時間）にて再発腫 瘍は消失した。第 2 回目の照射後 7 カ月たった昭和 57 年 1 月，下顎歯牙の動摇がみられ，X線所見で，歯槽骨の 退縮, 骨体の軽度び漫性骨吸収像と骨硬化像が認められ

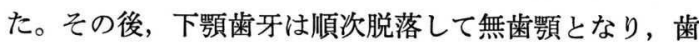

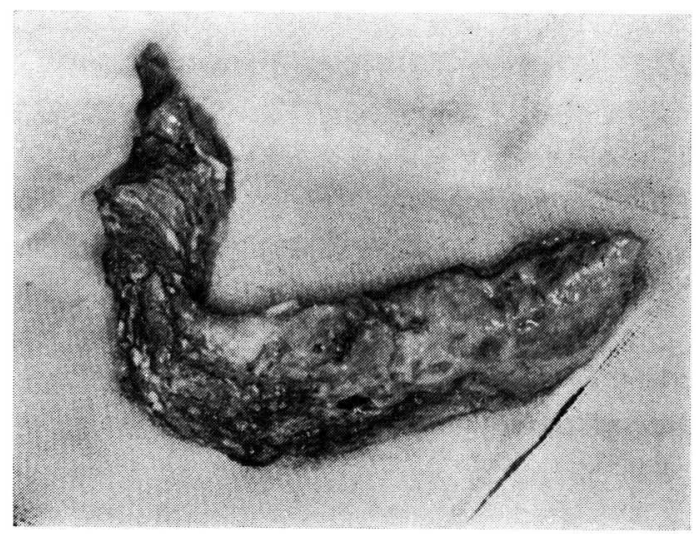

図

槽骨が口腔内に露出したので, 消炎療法をくり返した。 昭和57年10月，下澦骨は $\overline{8-\mid-8}$ 部位にわたり腐骨となっ て歯肉煩移行部まで露出しており，X線所見で，骨体の 広範な虫喰い状の骨吸収像と, 両側䫟角部における腐骨 の分離が進行していた。昭和 58 年 2 月 3 日, 患者は口唇 の腫脹を訴えて離島より来院した。当時下颚骨は両側に わたり腐骨となって口腔内に突出しており, 可動性を示 したので, 無麻醉下で腐骨の摘出を試みたところ, 正中 部で骨折して容易に摘出できた。

\section{摘出物の病理組織学的所見}

骨質はすべて壊死骨で，骨䯣組織は融解・消失してお り，骨髄腔およびハヴァース管内には壊死組織と多量の 細菌塊がみられ, 放射線骨壊死に細菌感染をおこした放 射線骨髄炎と診断された。

摘出直後のX線所見で, 骨体相当部に, 両側下顎上行 枝と不連続な少量の骨増生物が認められた。

初診より 6 年 2 カ月後で, 腐骨摘出 2 年後の現在, 顔 貌はオトガイ部の後退による鳥貌を呈するが，口腔内よ り触診で下顎弓に沿った骨の形成がみられ，X線所見で 上行枝と癒合した骨新生が認められた。なお, 患者は再 発転移などなく経過良好である。 


\section{1。下顎歯肉部に転移をみた肺癌の 2 症例}

\section{小林 明男（埼玉医科大学・口腔外科）}

顎口腔領域に転移性腫瘍を䜅めることは比較的まれで あり，大部分は原発性腫暗である。Mayer（1965年）ら によると，2400余例中，転移性腫瘍は25例で $1 \%$ 前後で あり，なかでも口腔内軟組織に転移をみることはきわめ て少なく 4 例であったと報告している。

今回われわれは, 下澦歯肉部に転移をした肺癌の 2 症 例を経験したのでここに報告した。

症例 $1: 69$ 歳, 男性

初 診：1982年10月23日

主 訴 : 7]歯肉部腫脹

現病歷：1981 年春頃より咳と痰がでるようになり， 1982年 3 月頃から背胸部痛を認めた。同年 9 月, 某病院 で胸部レントゲン検查施行, 咳と痰の増強はなかった が，左上肺野に腫瘤陰影を認めたため埼玉医大内科に紹 介された。この間 4 カ月間で約 $3 \mathrm{~kg}$ の体重減少があっ た。内科にて精查中，10月頃から 7 部異和感を訴え，徐 々に同部歯肉が腫脹してきたため, 当科受診。

現 症 : 口腔内7周囲の歯肉は，歯牙をかこむ様に発 赤腫脹，潰瘍形成はない。レントゲン上同部の骨破壊像 はみられず，7打診痛（一，開口障害はない。

処置ならびに経過：転移性腫腸を疑い，同部腫場を生 検したところ，腫瘍細胞は濃染する小型円形ないし棈円 形を呈し，胞体にそしく， small cell carcinoma で肺が 原発と考えられた。その後生検により，肺腫瘍も small cell carcinoma 々診断された。化学療法 (cyclophosphamide, oncovin, MTX)，放射線療法を行い，一時肺な らびに歯肉腫瘍の縮少をみたが，1983年 4 月12日死亡。

症例 $2: 72$ 歳, 男性。

初 診: 1984年 9 月 25 日

主 訴：下顎前歯部の腫瘤
現病歴：1984年 7 月 10 日, 脳梗塞にて埼玉医大内科入 院。胸部レントゲン写真で左上肺野に 腫瘤陰影をみと め, 肺癌 (左 $\mathrm{S}^{3}$ ) と診断された。9 月18日, 左肺上葉切 除，縦隔廓清術を施行した（病理診断，Large cell carcinoma）。8月下旬比から下䫟前歯部に米粒大の腫瘤がみ られ，術後増大してきたため当科受診。

現 症：口腔内 23 唇側滋 $11 \times 11 \mathrm{~mm}$ 大, 有茥 性，弾性軟の腫瘤を認め，被覆粘膜は軽度発赤，滑沢で 潰瑒形成はない。歯牙レントゲン写真では全体に歯槽骨 のビマン性吸収像を認めるが，腫瘤部に一致した特異的 な所見はない。

\section{処置ならびに経過}

転移性腫瘍も疑われたため同部を生検したところ，病 理組織像は肺癌のそれときわめて類似しており, 腫瘍細 胞は一部に角化傾向と粘液産生の両像を含んでいるが全 体として細胞は未熟大型であり, Large cell carcinoma の転移と診断された。歯肉腫瘍の増大傾向が著しく，咀 嚼障害があるため，10月18日腫場切除。10月31日死亡。

\section{考案}

歯肉部の転移腫場は少なく, 演者も涉猟した本邦の報 告例は56例であり，このうち骨破壊の認められなかった ものは33例であった。原発臟器としては, 子宮20例, 肺 19例, 腎 8 例, その他 9 例で, 最近の 10 年間では特に肺 癌の転移例が多い。顎骨転移では上顎骨と比べて下效骨 に多いと言われているが，歯肉転移例では上下䪹に差は みられず，歯肉の腫脹あるいは腫瘤形成を主訴とするむ のが多い。このことは, epulis, progenic granuloma, hemangioma, fibroma 等との鑑別が重要であり, 稀で はあるが口腔内病変が初発症状である場合もあり，診断 に際しては転移性腫富も十分念頭におく必要がある。 


\section{2.下顎骨骨肉腫の 1 症例}

飯田 英信・斉藤雄一郎・長谷川 等・木田 亮紀

富田寛学・耳鼻咽喉科）

骨肉腫は骨原発悪性腫場のうち，もっとも頻度が多く きわめて悪性度の高いものである。一般には長管骨, 特 に大腿骨, 脛骨に好発するが，下顎骨に発生することは 稀である。われわれは下顎骨に発生した骨肉腫の一例を 経験したので, その概要を報告する。

症 例 : 28歳, 女性

初 診: 昭和 57 年 9 月 21 日

主 訴: 左耳の前下部の腫脹および疼痛

家族歴，既往歴：特記すべきことなく，外傷の既往な ᄂ

現病歴 : 昭和 57 年 6 月より, 左耳の前下部の無痛性の 腫脹に気付き，某外科を受診したが原因不明といわれ た。徐々に増大し, 8 月より, 腫脹部の疼痛と開口障害 を来たしたため, 当科を受診した。

現 症 : 体格, 栄養中等度。胸部, 腹部には異常を認 めなかった。血清生化学検查にて, アルカリフォスファ ターゼが952単位と高值を示した。

左耳の前下部に自発痛㧍よび圧痛を伴う小児手拳大の 骨様の硬い腫瘤を認めた。皮膚との癒着はないが，可動 性は全くなかった。開口は 2 横指まで可能で, 口腔内に 異常所見はなく，頸部リンパ節む触知しなかった。

$\mathbf{X}$ 線所見：左下顎枝を中心に骨硬化像を伴った不規則 な骨吸収破壞像を認めた。骨肉腫のX線像の特徽とされ る sun-ray appearance は認められていない。

治療および経過：下澦骨腫瘍を疑い，昭和57年11月 17 日針穿刺組織診を施行し，その結果骨肉腫が疑われ，12 月 13 日入院した。12月 14 日, 左浅側頭動脈よりポリエチ レンチニーブを逆行性に挿入した。第1日目に CPM $400 \mathrm{mg}, \mathrm{ADM} 40 \mathrm{mg}$ 動注, VCR $2 \mathrm{mg}$ 静注し, 3 日 目より 8 日目まで CDDP を1 日 $20 \mathrm{mg}$ 動注にて投与し た。脱毛および白血球減少を認めたが, 回復後, 再度 1 コース施行した。下顎部の腫瘤の明らかな縮小沈認めら れなかった。しかし, 入院時, 血清アルカリフォスファ ターゼ值は1402単位と著明な高值を示していたが， 2 コ 一ス終了後, 231 単位と, 正常範囲までに低下した。昭 和58年 2 月 18 日, 下記の手術を行なった。

手術所見 : 気管切開後, 気管内㧌管下, 全身麻酔によ り上顎骨部分切除, 下顎骨部分切除および頸部郭清術を 施行した。腫瘍は左下顎枝に原発したものと思われ，下
方は下顎角まで，上方は頭蓋底值下まで及び，前方は上 䫟洞後壁を圧迫性に融解しており骨膜のみ残存してい た。頸部リンパ節転移は認められなかった。左側下顎骨 を第一大四歯の部で切断し, 顔面神経を一時的に切断 し, 上頡骨の一部と耳下腺浅葉を含め en bloc に摘出し た。摘出後, 顔面神経を再縫合し, 下顎の即時再建はせ ず，頡間固定を行ない，手術を終了した。摘出標本につ いて病理学的検索を行なったところ, 骨肉腫の診断を得 た。

術後経過 : 血清アルカリフォスファターゼ值は, さら に167単位と低下した。術後経過良好で， 5 週後に顎間 固定を除去し, 澦偏位予防のため, エリック・アーチ・ バーとエラスチックを使用した。2 カ月後, 滑面板を装 着し咬合機能を回復した。局所再発, 肺転移などの所見 もなく，6月 9 日退院となった。術後 2 年を経過した現 在, 顔面神経の不全麻瘦を認めるが, 再発, 転移は見ら れていない。

考 察: 骨に発生する腫湯のらち, その悪性度の高い ことから, 骨肉腫の占める位置はきわめて重要である。 発生部位としては大腿骨遠位端, 脛骨近位端および上腕 骨近位端に好発する。下顎骨原発の骨肉腫は, 本邦での 報告沙なく，自験例を含めて 56 例である。性別は男 性 : 女性 $=4: 7$ で，女性に多い。発病年齡は 8 歳 70 歳で, 平均33.0歳, 20 歳台にピークがある。骨肉腫の病 因は不明だが，まれに PAGET 病, fibrous dysplasia に続発するものや, 放射線治療後10数年して発生した症 例も報告されている。

骨肉腫の治療は従来, 根本手術が第一選択であり, 放 射線や制癌剂に対する感受性が低いとされていた。しか し近年になって, 高圧X線や速中性子線照射が実用化さ れ, また多剂併用化学療法が進歩し, 現在では, これら と手術を組み合わせた併用療法が主流となりつつある。 䫟骨骨肉腫は以前より $25 \%$ 以上の 5 年生存率が期待でき るといわれており，下顎骨に限れば $41 \%$ の 5 年生存の報 告もある。本症の予後の向上のために, 放射線, 化学療 法によって腫瘍を鎮静化させ，あるいは，すでに成立し ていると考えられる微小遠隔転移巣の撲滅を図った後に 原発腫瘍を完全に摘出する必要があると思われる。 